\title{
Pengembangan Bahan Ajar Trigonometri Berbasis Kearifan Lokal
}

\author{
Atika Nurafni $^{1 *}$, Heni Pujiastuti ${ }^{2}$, Anwar Mutaqin $^{3}$ \\ 1,2,3 Universitas Sultan Ageng Tirtayasa \\ *atikanurafni@gmail.com
}

Diterima: Oktober 2019. Disetujui: Desember 2019. Dipublikasikan: Januari 2020.

\begin{abstract}
ABSTRAK
Tujuan penalitian ini adalah menghasilkan bahan ajar matematika melalui pendekatan kearifan lokal pada materi trigonometri yang layak dan sesuai kebutuhan siswa. Jenis penelitian ini adalah Penelitian dan Pengembangan (R\&D) dengan menggunakan model ADDIE yang terdiri dari lima tahap, yaitu analyze (analisis), design (perancangan), development (pengembangan), implement (implementasi), dan evaluate (evaluasi). Instrumen yang digunakan yaitu lembar angket validasi ahli materi dan ahli media, angket respon guru matematika, dan angket respon siswa. Berdasarkan penelitian diperoleh hasil validasi ahli dengan persentase $80 \%$ (layak), respon guru dengan persentase $79 \%$ (baik), dan respon siswa dengan persentase $78 \%$ (baik). Secara keseluruhan bahan ajar ini dapat di terima dengan baik oleh guru dan siswa didukung oleh hasil validasi dari para ahli yang menyatakan bahan ajar layak digunakan untuk kegiatan belajar.
\end{abstract}

Kata kunci: bahan ajar, trigonometri, kearifan lokal.

\section{ABSTRACT}

The purpose of this research is to produce mathematics teaching materials through a local wisdom approach to trigonometry material that is appropriate and in accordance with the needs of students. This type of research is Research and Development $(R \& D)$ using the ADDIE model which consists of five stages, that is analyze, design, development, implement and evaluate. The instrument used were questionnaire validation sheet material experts and media expert, mathematics teacher response questionnaire and student response questionnaire. Based on the research results obtained by expert validation with a percentage of $80 \%$ (feasible), teacher response with a percentage of $79 \%$ (good) and responses students with a percentage of $78 \%$ (good). Overall this teaching material can be well received by teachers and studens, supported by validation results from experts who claim teaching materials are suitable for use in learning activities.

Keywords: teaching materials, trigonometry, local wisdom.

How to Cite: Nurafni, A., Pujiastuti, H., \& Mutaqin, A. (2020). Pengembangan Bahan Ajar Trigonometri Berbasis Kearifan Lokal. Journal of Medives: Journal of Mathematics Education IKIP Veteran Semarang, $4(1), 71-80$. 


\section{PENDAHULUAN}

Kegiatan pembelajaran adalah suatu aktivitas yang melibatkan banyak komponen. Bahan ajar merupakan salah satu komponen yang harus ada, karena bahan ajar dijadikan sebagai sarana belajar bagi siswa. Guru memiliki peran penting dalam memilih bahan ajar agar sesuai dengan bahan materi yang akan dikuasai oleh siswa dan sekaligus dapat memberikan pedoman untuk mempelajarinya. Untuk itu maka bahan ajar harus dikaji, dicermati dan dipelajari terlebih dahulu oleh guru, sehingga siswa dengan mudah dapat mempelajari materi (Dimyati \& Mudjiono, 2009).

Keberhasilan kegiatan pembelajaran dapat diperoleh apabila terdapat komponen yang dikembangkan oleh guru, yaitu tujuan, materi, strategi, dan evaluasi pembelajaran. Salah satu upaya guru yang dilakukan untuk mencapai keberhasilan pembelajaran adalah dengan mengembangkan bahan ajar yang dapat menimbulkan gairah siswa dalam belajar (Hosnan, 2016). Bahan ajar merupakan faktor eksternal siswa yang mampu memperkuat motivasi internal untuk belajar.

Menurut Direktorat Pembinaan Sekolah Menengah Atas (2008:6), bahan ajar adalah segala bentuk bahan yang digunakan untuk membantu guru dalam melaksanakan kegiatan belajar mengajar. Bahan yang dimaksud bisa berupa bahan tertulis atau tidak tertulis. Hal yang sama juga dikatakan oleh Prastowo (2012:16), bahan ajar adalah seperangkat materi yang disusun secara sistematis baik tertulis maupun tidak tertulis sehingga tercipta lingkungan yang memungkinkan siswa untuk belajar. Dari pengertian tersebut dapat dikatakan bahan ajar merupakan komponen penting yang digunakan guru dalam kegiatan belajar mengajar untuk mengarahkan siswa belajar. Bahan ajar dikelompokkan menjadi dua jenis yaitu, bahan ajar cetak yaitu: buku, modul, LKS, handout, brosur, leaflet, gambar dan model dan bahan ajar non cetak atau audio yaitu: kaset, radio, media interaktif (Pembinaan SMA, 2010).

Menurut Masduki \& Buchori (2014), mengatakan bahwa sebagian guru matematika yang mengajar di SMK masih menggunakan bahan ajar berupa buku yang diberikan oleh pemerintah tanpa memperhatikan isi dan pendekatan yang ada di dalam buku tersebut. Hal ini tidak baik dilakukan oleh guru karena mengakibatkan kurangnya minat siswa terhadap matematika. Guru sebagai fasilitator yang membantu mengarahkan siswa dalam belajar, harus dapat mengarahkan siswa menjadi pembelajar yang aktif agar siswa dapat membaca dan mempelajari dahulu sebelum mengikuti pembelajaran dikelas dan siswa sudah siap dengan bekal informasi yang didapatkan sebelum pembelajaran (Malati, 2012). Oleh karena itu seorang guru sangat perlu mengembangkan bahan ajar yang sesuai dengan tuntutan kurikulum dengan mempertimbangkan kebutuhan siswa, yakni bahan ajar yang sesuai dengan karakteristik siswa sebagai sasaran. Karakteristik tersebut meliputi lingkungan sosial, budaya, geografis maupun tahapan perkembangan siswa. Bahan ajar yang dikembangkan juga harus dapat menjawab dan memecahkan masalah atau kesulitan dalam belajar. 
Pengembangan bahan ajar yang sesuai dengan karakteristik siswa dan lingkungan sosial budaya sangat dibutuhkan saat ini, karena pendidikan karakter yang seharusnya ditanamkan kepada siswa seringkali hanya dianggap biasa saja atau tidak dipentingkan. Pada pelaksanaan Kurikulum 2013 yang sudah diterapkan oleh sekolah-sekolah terdapat karakteristik pendekatan pembelajaran saintifik dengan prosedur $5 \mathrm{M}$ (mengamati, menanya, mengekplorasi, mengasosiasi, dan mengkomunikasikan). Karakteristik pendekatan saintifik itu lebih bermakna jika pembelajaran dikemas menggunakan benda-benda, peristiwa-peristiwa dan masalah yang berkaitan dengan kehidupan sehari-hari. Konsep ini biasanya dikenal dengan konsep pembelajaran dengan menggunakan kearifan lokal (Sunandar, 2018). Kearifan lokal yang digunakan dalam pembelajaran dapat berbentuk nilai atau kearifan lokal dalam bentuk bukan nilai (Kharis A, 2017). Kearifan berbentuk nilai misalnya nilai keagamaan yang sangat kental di daerah Banten dengan banyaknya tempat untuk ziarah, diharapkan siswa menjadi lebih religious dengan menghayati dan mencintai agama yang dianutnya. Hal ini sesuai dengan kompetensi inti yang diharapkan oleh kurikulum 2013. Sedangkan kearifan lokal berbentuk bukan nilai yang dimasukkan dalam pembelajaran, misalnya melalui bangunan-bangunan bersejarah, budaya khas daerah, dan potensi-potensi yang terdapat dalam suatu daerah, akan menambah rasa cinta kepada daerah dan potensi kelokalan siswa akan tetap kukuh terjaga di tengahtengah derasnya arus globalisasi.
Permendikbud Nomor 22 Tahun 2016 dalam kegiatan pendahuluan harus diberikan potensi daerah. Potensi daerah atau pengetahuan kedaerahan dapat dimasukkan dalam contoh soal maupun contoh permasalahan. Mengajar dengan contoh kongkret dapat diimplementasikan untuk meningkatkan kemampuan berfikir siswa tingkat tinggi dalam pemecahkan masalah (Syahputra, 2017). Tetapi kenyataannya banyak buku yang masih belum menggunakan materi kedaerahan (Kharis A, 2017). Keuntungan memasukkan materi kedaerahan dalam pembelajaran adalah siswa sudah mengetahui tentang masalah yang dibicarakan sehingga siswa dapat menangkap maksud dari pelajaran yang dipelajari. Guru dapat menjelaskan pembelajaran menggunakan contoh permasalahan yang sesuai dengan mengkaitkan kearifan lokal dan juga dapat menyampaikan materi dengan bahasa yang sesuai dengan tingkat berfikir siswa.

Penggunaan istilah asing yang tidak sesuai dengan bahasa daerah terkadang membuat siswa menjadi bingung karena tidak mengerti arti dari istilah yang digunakan. Hal ini sesuai dengan pendapat Azzizah (2015), mengatakan bahwa guru harus meluangkan waktu untuk menerjemahkan istilah yang tidak dimengerti siswa ke dalam bahasa yang dimengerti siswa. Penyampaian bahan belajar dengan menggunakan bahasa daerah dan materi yang memuat unsur kedaerahan dapat mendapatkan keuntungan siswa lebih mengenal daerah asalnya dan mengetahui kearifan lokal dari daerah lain. Pada era yang serba moderen ini kearifan 
lokal, budaya lokal dan ciri khas kedaerahan semakin ditinggalkan (Bakhtiar, 2016). Hal ini menyebabkan seseorang tidak dapat mengenali, mengembangkan dan menerapkan nilai-nilai kearifan daerahnya karena pembelajaran di sekolah-sekolah kurang memperhatikan secara khusus aspek lokal ini. Sebagai contoh Jepang adalah negara yang berhasil dalam mempertahankan tradisitradisinya lewat pendidikan meskipun bangsanya sudah maju dan moderen.

Perkembangan teknologi telah membuat perubahan yang luar biasa, salah satunya adalah perkembangan teknologi informasi dan komunikasi (Pujiastuti \& Haryadi, 2019). Untuk menguasai dan menciptakan teknologi di masa depan diperlukan penguasaan matematika yang kuat sejak dini. Matematika merupakan ilmu universal yang mendasari perkembangan teknologi moderen dan memiliki peran penting diberbagai disiplin ilmu dan melatih daya pikir manusia. Menurut Badan Standara Nasional Pendidikan matematika diberikan kepada semua siswa mulai sekolah dasar untuk membekali siswa dengan kemampuan berfikir logis, analitis, sistematis, kritis dan kreatif serta mampu bekerjasama. Matematika diajarkan bukan hanya sekedar tentang fakta-fakta yang dihafalkan tetapi matematika diajarkan agar siswa mampu mengkaji dan berfikir, karena matematika merupakan ilmu dasar yang mempunyai peranan dalam ilmu terapan.

Melihat pentingnya matematika maka peningkatan mutu pendidikan menjadi prioritas utama terutama oleh siswa tingkat SMA, apalagi untuk siswa SMK dalam memasuki dunia kerja.
Siswa Sekolah Menengah Kejuruan (SMK) dituntut untuk mengikuti perkembangan zaman yang semakin moderen dan harus memiliki kemampuan kompetensi yang sesuai dengan dunia kerja dan dunia industri (Mahmudi, dkk, 2015). Salah satu materi matematika yang sulit dikuasai oleh sebagian siswa adalah materi Trigonometri. Trigonometri merupakan materi yang dapat dihubungkan dengan kearifan lokal sebagai contoh nyata dalam pembelajaran.

Dalam mengembangkan bahan ajar diperlukan desain yang tepat. Seorang guru harus memiliki kemampuan mendesain bahan ajar yang baik agar dapat dipergunakan untuk kegiatan mengajar (Yogaswara, 2019). Hal tersebut sesuai dengan pendapat Suryadi (2010), yang mengatakan bahwa keberhasilan pembelajaran antara lain terkait erat dengan disain bahan ajar (disain didaktik) yang dikembangkan guru. Karena obyek matematika bersifat abstrak dan aktivitas bermatematika terjadi secara mental, maka proses pendisainan bahan ajarnya perlu mempertimbangkan proses berpikir tentang konsep yang akan diajarkan khususnya dari sudut pandang ahli matematika, guru matematika, dan orang yang belajar matematika.

Berdasarkan observasi juga wawancara kepada beberapa guru yang mengajar matematika dalam forum diskusi guru di kabupaten Pandeglang, menyatakan bahwa buku siswa terbitan Kemdikbud belum sesuai dengan karakteristik siswa di SMK. Karena lingkungan sosial, budaya dan karakteristik sasaran pada tahap kemampuan awal yang kurang, latar belakang 
keluarga dan lainnya, sehingga siswa kurang berminat terhadap buku tersebut. Hal ini sesuai dengan penelitian yang dilakukan Ni'mah Zahrotun (2014), bahwa buku siswa terbitan Kemendikbud termasuk kategori kurang layak dalam hal spiritual, dan kategori baik pada dimensi sosial, pengetahuan dan keterampilan. Sedangkan buku ajar yang baik menurut BSNP (2011) harus layak dalam isi materi, bahasa, penyajian dan kegrafikan. Kelayakan buku berarti buku tersebut dikategori baik atau sangat baik.

Berdasarkan uraian yang telah dikemukakan maka peneliti ingin melakukan penelitian tentang bahan ajar berupa bahan ajar yang sesuai dengan karakteristik siswa baik secara sosial, budaya, geografis tempat tinggal siswa dan kondisi sehingga tujuan pembelajaran matematika bisa tercapai. Hal ini didukung penelitian yang dilakukan oleh Dazrullisa (2018), mengenai "Pengaruh pembelajaran matematika berbasis kearifan lokal terhadap minat belajar siswa" didapatkan $76,16 \%$ siswa berminat mempelajari matematika berbasis kearifan lokal dan hasil belajar siswa $82 \%$ mencapai ketuntasan.

Rumusan masalah dalam penelitian ini adalah bagaimana mengembangkan bahan ajar trigonometri melalui kearifan lokal. Tujuan dari penelitian ini untuk mengetahui cara mengembangkan bahan ajar trigonometri pada siswa SMK kelas X. Adapun manfaat dari penelitian ini adalah bahan ajar diharapkan dapat turut serta menjaga kearifan lokal dari daerah Banten dan sebagai upaya memperkenalkan dan mendekatkan diri terhadap nilai-nilai budaya di daerahnya, serta sebagai sumber atau bahan pendidikan. Sesuai dengan Peraturan Gubernur Banten No. 7 tahun 2012 pasal 22 bahwa "setiap satuan pendidikan di daerah wajib menyusun kurikulum yang tanggap terhadap ilmu pengetahuan, teknologi, seni, dan budaya”.

\section{METODE PENELITIAN}

Jenis penelitian ini adalah penelitian pengembangan atau Research and Development (R\&D). Sugiyono (2017) menyatakan bahwa metode R\&D adalah metode yang digunakan untuk menghasilkan produk tertentu, dan menguji keefektifan produk tersebut. Produk yang dihasilkan dalam penelitian ini adalah bahan ajar yang di dalamnya membahas materi trigonometri. Model $\mathrm{R} \& \mathrm{D}$ yang digunakan pada penelitian ini adalah ADDIE yang terdiri dari 5 tahap, yaitu: analyze (analisis), design (perancangan), development (pengembangan), implement (implementasi), dan evaluate (evaluasi). Penelian dilakukan pada siswa kelas X SMKN 4 Pandeglang pada bulan Juni 2019 menggunakan angket. Adapun tahapan ADDIE tersebut dijelaskan sebagai berikut.

\section{Analyze (Analisis)}

Kegiatan pada tahap ini dilakukan untuk menganalisi kebutuhan. Secara umum kegiatannya meliputi mencari informasi mengenai karakteristik siswa, melakukan diskusi dalam forum MGMP untuk menentukan bahan ajar yang sesuai dengan karakteristik siswa, menentukan jenis bahan ajar yang akan dikembangkan, menggumpulkan bahan ajar yang sudah ada di pasaran sebagai penunjang. 


\section{Design (Perancangan)}

Tahap kedua adalah membuat desain media yang akan dibuat. Desain tersebut disusun dengan mengamati masalah kemudian mencari solusi berdasarkan analisis. Tahap ini bertujuan untuk menyiapkan suatu rancangan bahan ajar yang akan dikembangkan dengan membuat format dari awal pembelajaran sampai ahir pembelajaran.

\section{Development (Pengembangan)}

Tahap ini bertujuan untuk menghasilkan draft bahan ajar yang telah direvisi berdasarkan masukan para ahli sehingga dapat diujicobakan kepada siswa. Beberapa hal yang dilakukan pada tahap ini adalah sebagai berikut.

\section{- Validasi Instrumen}

Instrument yang telah dirancang pada tahap sebelumnya terlebih dahulu divalidasi agar dapat mengukur validitas perangkat pembelajaran yang dikembangkan.

\section{- Validasi Produk}

Validasi produk digunakan untuk mengetahui kelayakan bahan ajar yang dikembangkan. Validasi desain merupakan proses untuk menilai rancangan produk. Bahan ajar divalidasi oleh 2 orang ahli untuk mengetahui layak atau tidaknya produk yang dikembangkan digunakan untuk pembelajaran. Adapun ahli yang diminta menjadi validator adalah dosen matematika di Universitas Sultan Ageng Tirtayasa dan guru matematika di SMKN 4 Pandeglang.

\section{Implementasi}

Pada tahap implementasi, hasil validasi dari para ahli tersebut digunakan oleh peneliti untuk memperbaiki atau menyempurnakan bahan ajar awal yang telah dibuat agar bahan ajar tersebut lebih relevan dan memenuhi kebutuhan standar siswa dan guru dalam kegiatan pembelajaran. Kemudian produk diujicobakan kepada guru dan siswa. Hasil uji coba kepada guru untuk mengetahui respon guru terhadap produk yang meliputi keefektifan dan kepraktisan produk, sedangkan hasil uji coba produk kepada siswa secara langsung untuk mengetahui respon siswa terhadap produk bahan ajar melaui angket yang meliputi keefektifan dan kemenarikan bahan ajar.

\section{Evaluasi}

Tahap ini dilakukan untuk kebutuhan revisi produk dan mementukan kelayakan produk akhir. Hasil validasi ahli dan uji coba lapangan dianalisis dengan menghitung persentase (\%) skor yang diperoleh dari semua ahli dan responden berdasarkan kriteria.

Tabel 1. Kriteria Interpretasi Skor Ahli Materi dan Ahli Media

\begin{tabular}{cc}
\hline Persentase & Kriteria \\
\hline $80 \%<\mathrm{P} \leq 100 \%$ & Sangat Layak \\
$60 \%<\mathrm{P} \leq 80 \%$ & Layak \\
$40 \%<\mathrm{P} \leq 60 \%$ & Cukup Layak \\
$20 \%<\mathrm{P} \leq 40 \%$ & Tidak Layak \\
$0 \%<\mathrm{P} \leq 20 \%$ & Sangat Tidak Layak \\
\hline
\end{tabular}

Tabel 2. Kriteria Interpretasi Presentasi Hasil Angket

\begin{tabular}{cc}
\hline Presentase & Kriteria \\
\hline $80 \%<\mathrm{P} \leq 100 \%$ & Sangat Baik (SB) \\
$60 \%<\mathrm{P} \leq 80 \%$ & Baik \\
$40 \%<\mathrm{P} \leq 60 \%$ & Cukup \\
$20 \%<\mathrm{P} \leq 40 \%$ & Tidak Baik (TB) \\
$0 \%<\mathrm{P} \leq 20 \%$ & Sangat Tidak Baik (STB) \\
\hline \multicolumn{2}{c}{ (Diadaptasi dari Riduan (2003:48)) }
\end{tabular}




\section{HASIL DAN PEMBAHASAN}

Proses yang dilakukan dalam pengembangan ini meliputi analisis, analisis dilakukan untuk mengetahui kebutuhan bahan ajar berdasarkan karakteristik siswa, desain atau perancangan adalah membuat rancangan produk yang akan dikembangkan, setelah perancangan produk selesai selanjutnya tahap pengembangan berdasarkan masukan dari para ahli dilakukan revisi kemudian bahan ajar diujicobakan kepada siswa. Bahan ajar yang dikembangkan divalida- si oleh 2 orang ahli materi dan 2 orang ahli media, serta diujicobakan kepada guru dan siswa melalui angket respon guru dan siswa.

\section{Validasi Kelayakan}

Penilaian kelayakan bahan ajar trigonometri dilakukan oleh validator, yaitu 2 orang ahli materi dan 2 orang ahli media. Hasil pengembangan dalam penelitian ini adalah bahan ajar trigonometri berbasis kearifan lokal dinyatakan layak digunakan.

Table 3. Hasil Validasi Penilaian Ahli Materi

\begin{tabular}{llcccc}
\hline Validator & Aspek Penilaian & Skor Jumlah & Pernyataan & Persentase (\%) & Kriteria \\
\hline \multirow{4}{*}{ Ahli Materi } & Kelayakan Isi & 127 & 20 & 79 & Layak \\
& Kelayakan Penyajian & 95 & 14 & 85 & Layak \\
& Kelayakan Bahasa & 86 & 13 & 83 & Layak \\
& Kearifan Lokal & 42 & 9 & 86 & Layak \\
Total & & 350 & 56 & 78 & Layak \\
\hline
\end{tabular}

Tabel 4. Hasil Validasi Penilaian Ahli Materi

\begin{tabular}{cccccc}
\hline Validator & Aspek Penilaian & Skor Jumlah & Pernyataan & Persentase (\%) & Kategori \\
\hline Ahli media & Kelayakan Kegrafikan & 113 & 16 & 88 & Layak \\
\hline
\end{tabular}

Tabel 5. Analisis Kevalidan Bahan Ajar

\begin{tabular}{ccccc}
\hline No & Validator & Skor Jumlah & Persentase (\%) & Kategori \\
\hline 1. & Ahli materi & 350 & 80 & Layak \\
2. & Ahli media & 113 & & \\
\hline
\end{tabular}

Persentase skor dari validator adalah $78 \%$. Berdasarkan tabel kriteria penilaian menunjukkan bahwa bahan ajar trigonometri berbasis kearifan lokal memenuhi kriteria aspek kelayakan isi, penyajian, bahasa, dan materi memuat kearifan lokal. Sehingga bahan ajar yang dikembangkan dikategorikan layak untuk digunakan dalam pembelajaran.

Persentase skor dari validator adalah $88 \%$. Berdasarkan tabel kriteria penilaian menunjukkan bahwa bahan ajar berbasis kearifan lokal memiliki penilaian layak. Hal ini menunjukkan bahwa bahan ajar memenuhi kriteria kesesuaian terhadap aspek kegrafikan. Berdasarkan penilaian oleh validator yaitu ahli materi dan ahli media, dapat dilihat pada Tabel 5.

Persentase skor yang diperoleh berdasarkan kedua validator ahli adalah $80 \%$. Dengan demikian maka dapat dikatakan bahwa bahan ajar trigonometri berbasis kearifan lokal tersebut dikategorikan layak digunakan dalam pembelajaran. 
Tabel 6. Respon Guru Matematika

\begin{tabular}{llcccc}
\hline Responden & Aspek Penilaian & Skor Jumlah & Pernyataan & Persentase (\%) & Kategori \\
\hline $\begin{array}{l}\text { Guru } \\
\text { Matematika }\end{array}$ & $\begin{array}{l}\text { Keefektifan dan } \\
\text { kepraktisan }\end{array}$ & 171 & 18 & 79 & Baik \\
\hline
\end{tabular}

Tabel 7. Respon Siswa

\begin{tabular}{llcccc}
\hline Responden & Aspek Penilaian & Skor Jumlah & Pernyataan & Persentase (\%) & Kategori \\
\hline Siswa & $\begin{array}{l}\text { Keefektifan dan } \\
\text { kemenarikan }\end{array}$ & 558 & 18 & 78 & Baik \\
\hline
\end{tabular}

\section{Respon Guru dan Siswa}

Setelah produk divalidasi oleh ahli dan diperbaiki sesuai dengan saran para ahli, kemudian produk diujicobakan kepada 3 orang guru dan 10 siswa, untuk mengetahui respon guru dan siswa terhadap keefektifan, kemenarikan produk. Hasil yang diperoleh dapat dilihat pada Tabel 6 .

Persentase skor dari responden guru adalah $79 \%$, berdasarkan tabel kriteria penilaian menunjukkan bahwa bahan ajar berbasis kearifan lokal memiliki penilaian baik. Hal ini menunjukkan bahwa bahan ajar memenuhi kriteria kesesuaian terhadap aspek keefektifan dan kepraktisan.

Persentase skor dari responden siswa adalah $78 \%$. Berdasarkan tabel kriteria penilaian menunjukkan bahwa bahan ajar berbasis kearifan lokal memiliki penilaian baik. Hal ini menunjukkan bahwa bahan ajar memenuhi kriteria kesesuaian terhadap aspek keefektifan dan kemenarikan.

\section{Evaluasi Produk}

Evaluasi produk dilakukan guna mendapatkan produk yang layak digunakan. Produk dievaluasi dan direvisi berdasarkan hasil penilaian dan saran dari validator. Berdasarkan hasil evaluasi setelah penilaian ahli, produk yang dikembangkan mengalami beberapa revisi. Di antaranya sistematika penyampaian materi, kalimat, kelengkapan materi, tingkat kesukaran soal, gambar dan grafik.

Produk ahir pengembangan bahan ajar adalah bahan ajar materi trigonometri yang sesuai dengan kebutuhan siswa SMKN 4 Pandeglang. Berdasarkan hasil validasi para ahli dengan persentase $80 \%$ (layak), respon guru dengan persentase 79\% (baik), respon siswa dengan persentase $78 \%$ (baik), dan perbaikan-perbaikan sesuai saran dari para ahli. Disimpulkan bahwa bahan ajar trigonometri berbasis kearifan lokal yang dikembangkan telah memenuhi kriteria layak dan baik digunakan untuk pembelajaran.

Berdasarkan dari hasil penelusuran ditemukan penelitian yang mirip dengan masalah yang diteliti yaitu: Pengembangan bahan ajar berbasis etnomatematika dalam pembelajaran matematika di Sekolah Menengah Pertama yang diteliti oleh Jarnawi Algani Dahlan dan Revina Permatasari, mahasiswa Universitas Pendidikan Indonesia tahun 2018. Dari hasil penelitian menunjukkan bahwa melalui bahan ajar berbasis etnomatematika pada topik himpunan mampu memfasilitasi siswa dalam menambah pengetahuan matematika 
secara induktif walaupun masih kesulitan dalam menyusun bentuk formal matematika, cukup kreatif dalam merespon permasalahan, mampu mengkomunikasikan gagasan, memunculkan rasa ingin tahu, mampu bekerja sama dengan penugasan peran yang jelas, serta tidak kalah penting adalah memperoleh pengetahuan tentang nilai-nilai sosial dan budaya yang ada di masyarakat.

\section{PENUTUP}

Berdasarkan hasil penelitian dan pengembangan bahan ajar, dapat disimpulkan bahwa bahan ajar trigonometri melalui pendekatan kearifan lokal yang dikembangkan, berdasarkan karakteristik siswa dan dapat menambah pengetahuan tentang ciri khas kelokalan daerah Banten. Tahapan pengembangan bahan ajar yaitu melalui tahap ADDIE. Tahap analyze (analisis) yaitu analisis kebutuhan, tahap design (perancangan) yaitu membuat solusi berdasarkan analisis dengan merancang bahan ajar yang sesuai, tahap development (pengembangan) yaitu membuat draft desain yang divalidasi oleh ahli materi dan ahli media, tahap implementation (implementasi) yaitu produk diujicobakan untuk mengetahui respon guru dan siswa dan tahap evaluate (evaluasi) yaitu mengevaluasi dan merevisi produk sesuai dengan arahan validator dan respon guru dan siswa.

Saran bagi peneliti yang akan mengembangkan bahan ajar berbasis kearifan lokal hendaknya memperhatikan kemampuan awal siswa, bahan ajar disusun dengan soal-soal yang bervariasi sehingga menambah pengetahuan siswa, dan dapat menjadi salah satu acuan untuk pembelajaran.

\section{DAFTAR PUSTAKA}

Azzizah, Y. (2015). Socio-Economic Factors on Indonesia Education Disparity. International Education Studies, $8(12)$ https://doi.org/10.5539/ies.v8n12p 218

Bakhtiar, D. (2016). Bahan Ajar Berbasis Kearifan Lokal Terintegrasi STM (Sains, Teknologi, dan Masyarakat) Pada Mata Pelajaran Fisika. In Universitas Jember (Vol. 1, pp. 650-660). Jember.

Dazrullisa. (2018). Pengaruh pembelajaran matematika berbasis kearifan lokal terhadap minat belajar siswa. Genta Mulia, IX(2), 141-149.

Dimyati, D., \& Mudjiono, D. (2009). Belajar dan pembelajaran (ix). jakarta: PT Rineka Cipta bekerjasama dengan Depdikbud.

Ferdianto, F., \& Setiyani. (2018). Pengembangan Bahan Ajar Media Pembelajaran Berbasis Kearifan Lokal Mahasiswa Pendidikan Matematika. JNPM (Jurnal Nasional Pendidikan Matematika), 2(1), 37-47.

Hosnan, M. (2016). Pendekatan Saintifik dan Konstektual dalam Pembelajaran Abad 21. (R. Sikumbang, Ed.) (3rd ed.). Bogor: Ghalia Indonesia.

Ikhwanudin, T. (2018). Pembelajaran Matematika Berbasis Kearifan Lokal Untuk Membangun Karakter Bangsa. Union: Jurnal Pendidikan Matematika, 6(1), 1118. 
Kharis A, M. (2017). Pengembangan Bahan Belajar Interaktif Berkonten Lokal Wisdom Dengan Format .Swf Untuk Pelajaran Matematika Sekolah Menengah Atas. Universitas Pendidikan Indonesia.

Mahmudi, A., Sugiman, Puji Lestari, H., \& Hernawati, K. (2015). Pengembangan Bahan Ajar Matematika Dengan Pendekatan Kontekstual Untuk Pembelajaran di SMK (Vol. 2). Yogyakarta.

Malati S, I. (2012). Hakikat Bahan Ajar. In 1 (pp. 1-62). Jakarta: Universitas Terbuka. Retrieved from

http://repository.ut.ac.id/4157/1/I DIK4009-M1.pdf

Masduki, L. R., \& Buchori, A. (2014). Pengembangan Bahan Ajar Matematika SMK Berbasis Softwere Geometers Sketchpad Dengan Pendekatan Ethnomathematic. Aksioma: Jurnal Pendidikan Matematika, 3(1), 75-80.

Ni'mah Zahrotun. (2014). Analisis Kelayakan Isi Buku Teks Siswa Matematika SMA/MA Kelas X Kurikulum 2013 Terbitan Kementrian Pendidikan dan Kebudayaan Tahun 2013. Semarang: Institut Agama Islam Negeri Walisonggo.

Pembinaan SMA, D. (2010). Petunjuk Teknis Pengembangan Bahan Ajar SMA.
Prastowo, A. (2012). Panduan Kreatif Membuat Bahan Ajar Inovatif. Yogyakarta: Diva Pres.

Pujiastuti, H., \& Haryadi, R. (2019). Interactive Math E-Book: An Alternative Learning Resources for 21 st Century Learners. https://doi.org/10.4108/eai.21-112018.2282046

Riduan. (2003). Dasar-dasar Statistika. Jakarta: Alfabeta.

Sugiyono. (2017). Metode Penelitian Kuantitatif, Kualitatif, dan $R \& D$ (26th ed.). Bandung: CV Alfabeta.

Sunandar. (2018). Pembelajaran matematika berbasis kearifan lokal. In SNPMAT (Vol. 1, pp. 114).

Suryadi, D. (2010). Penelitian Pembelajaran Matematika Untuk Pembentukan Karakter Bangsa. In Seminar Nasional Matematika dan Pendidikan Matematika (pp. 114). Yogyakarta: Tarsito.

Syahputra, E. (2017). The Development of Learning Model Based on Problem Solving to Construct High-Order Thinking Skill on the Learning Mathematics of 11 th Grade in SMA / MA. Journal of Education and Practice, 8(6), 8085.

Yogaswara, Y. (2019). Pengembangan Bahan Ajar Berorientasi Penguatan Pendidikan Karakter dalam Pembelajaran Matematika SMA pada Materi Statistika. Universitas Sultan Ageng Tirtayasa. 